\title{
Relationship between Board Structure and Volatility of Stock Returns of Selected Companies Listed on BSE
}

\author{
Fatemeh Mohammadhosseini ${ }^{1}$, Dr. H. Rajashekar ${ }^{2}$ \\ ${ }^{1}$ Fatemeh Mohammadhosseini. Research Scholar, Department of Studies in Commerce, \\ University of Mysore, Mysuru \\ ${ }^{2}$ Dr. H. Rajashekar, Professor and Director (EMRC), Department of Studies in Commerce, \\ University of Mysore, Mysuru
}

\begin{abstract}
Good corporate governance enhances the quality of listed companies. It forms a scientific constraint and necessary incentive mechanism that motivates managers to take risks, leading to increased company value. The study considered cement, iron, and steel companies listed on the Bombay Stock Exchange (BSE) to assess the relationship between board structure and volatility of stock returns. The study's main objective was to analyze the relationship between board structure and volatility of stock returns. The relationship between board structure and volatility of stock returns was tested using SPSS through descriptive statistics, f-test, and multiple regression models. It was found that board structure possessed a positive relationship with the volatility of stock returns during the study period.
\end{abstract}

Keywords: Board Structure, Bombay Stock Exchange, Corporate Governance and Volatility of Stock Returns

\section{Introduction}

When companies design and implement these systems desirably, they increase the financial system in society by increasing investment amounts in companies and improving economic growth. The desired governance system of a company can lead to improved company performance and consequently more access to foreign capital of company, thus it can provide sustainable economic growth. On the other hand, effective implementation of a governance system leads to resource allocation in the best way. This will be associated with more growth and productivity, leading to economic stability growth.

Good corporate governance is also a firm foundation for healthy securities markets in the long run. It reduces speculation and violations of market rules and thereby helps ensure stability in the financial markets. It enhances the quality of listed companies and forms a scientific constraint and necessary incentive mechanism that motivates managers to take risks, leading 
to increased company value. Furthermore, it creates fairness, transparency, and accountability in its business activities. A governance system of high quality includes tools and mechanisms that ensure the following:

1. The management targets to maximize investors' wealth and prosperity.

2. Company legislation protects the rights of minority shareholders and limits controlling shareholders.

3. Most board members are non-binding members (Fox and Heller, 2000).

The most important concepts in investment decisions are risk and return. Each stock or portfolio of stocks is purchased at a specific time interval, retained, and sold. It gives an inevitable return to Investor. This return includes changes in prices and benefits derived from ownership (Raei and Saidi, 2004). On the other hand, stock returns in different periods vary, not bringing a constant trend. Therefore, this fluctuation and variability are only integral to stock returns over time. Variance and volatility of stock returns lead to risky investments. Thus, the investor always seeks to reduce the risk and increase the assurance of returns (Raei, 1998).

\section{Review of Literature}

Roy, A. (2016) studied Corporate Governance and Firm Performance: A Study of Indian Listed Firms. The study used a panel of 58 top Indian listed companies in market capitalization BSE 100 and NSE 100 over five years from 2007-2008 to 2011-2012 for our analysis. The measurement analysis started with a broad sample of 25 structural indicators of CG relating to Directors, Boards committees, audit considerations, ownership and capital structure characteristics, and our defined set of control variables. Two firm performance measures were used: Market to Book Value Ratio (MTBVR) and Return on Equity (ROE). Principal Component Analysis was used to identify the underlying dimensions of CG, and determining indicators were associated with each factor. The researcher regressed MTBVR and ROE against the factor scores generated. MTBVR resulted in an R-square of 34.9 percent and was strongly associated with five factors. ROE resulted in an R-square of 48.6 percent and was significantly influenced by the five factors.

Manna, A., Sahu, T. N., \& Gupta, A. (2016) studied the Impact of Ownership Structure and Board Composition on Corporate Performance in Indian Companies. This study took Impact of Ownership Structure and Board Composition on Corporate Performance in Indian Companies. They considered the National Stock Exchange (NSE)-listed Indian companies, which constituted the CNX Nifty Index from 2009 to March 2013. Tobin's Q, market valueadded, cash earnings per share, and return on capital employed have been used as the corporate performance variables in the study. Board size (BS), board composition, ownership structure, the diversity of directorship, chief executive officer (CEO) duality, CEO tenure, and executive remuneration were used as corporate governance surrogates from different dimensions along with other widely used independent variables to see their effect on corporate performance in a panel-data-based regression. BS and foreign promoters' (FPs') shareholdings were identified to impact more than one corporate performance variable positively. Among the remaining independent variables, asset turnover was positively related to performance variables. 
Tusiime, I.; Nkundabanyanga, S. K. and Nkote, I. N. (2011), the researchers in their paper have attempted to explain the Corporate Governance: Ownership Structure, Board Structure, and Performance of Public Sector Entities. This study examines ownership structure, board structure, and their relationship with Uganda's public sector entities' performance. A crosssectional and correlation research design with a sample of 85 public sector entities in Uganda was used. Findings indicated that $67 \%$ of the variance in public sector entities' performance was explained by ownership structure and board structure. The results portrayed that CEO duality was not yet an issue as far as the performance of public sector entities in Uganda was concerned. Evidence had emerged that it was necessary to reduce government ownership in public sector entities in Uganda to achieve better performance.

\section{Objectives of the Study}

- To examine the relationship between board structure and volatility of stock returns in the selected Iron \& Steel and Cement companies.

\section{Research Hypothesis}

$\mathrm{H}_{01}$ : There is no significant difference among Iron \& Steel and Cement companies with respect to the relationship between board structure and volatility of stock returns.

$\mathrm{H}_{1}$ : There is a significant difference among Iron \& Steel and Cement companies with respect to the relationship between board structure and volatility of stock returns.

\section{Research Methodology}

The research used secondary data, and to collect data relating to board structure and volatility of stock returns, annual reports of sample companies for the financial years 2011-2018 were used. The collected data were then analyzed using the statistical SPSS software. The data were analyzed using descriptive statistics, f-test, and multiple regression models.

$\operatorname{VOL}_{i t}=\beta_{0}+\beta_{1}$ BOARD STRUCTURE $_{i, t}+e_{i, t}$

VOLit : volatility of stock returns of $\mathbf{i}$ company in the $\mathbf{t}$ year.

BOARD $\mathrm{i}, \mathrm{t}$ : score will be calculated for the board structure of $\mathbf{i}$ company in the $\mathbf{t}$ year.

\section{Volatility of Stock Returns Models}

The dependent variable of this study was the volatility of stock returns that would be measured as the standard deviation of daily stock returns.

$$
\mathrm{VOL}_{\mathrm{i}, \mathrm{t}}=\sqrt{\frac{1}{\mathrm{D}_{\mathrm{it}-1}} \sum_{1}^{\mathrm{D}_{\mathrm{it}}}\left(\mathrm{R}_{\mathrm{i}}-\overline{\mathrm{R}}\right)^{2}}
$$

Where;

$\mathrm{VOL}_{\mathrm{i}, \mathrm{t}}$, volatility of stock return of $\mathrm{i}$ company in the $\mathrm{t}$ year, 
$R_{i}$ is Daily stock returns of the $i$ company that if $P_{t}$ is the final price of the $t$ day

\section{Data Analysis and Interpretation}

\section{Descriptive Statistics}

Table 1: Descriptive Statistics of Board Structure in Cement and Iron \& Steel Companies

\begin{tabular}{|c|c|c|c|c|c|}
\hline & Mean & Maximum & Minimum & $\begin{array}{c}\text { Standard } \\
\text { Deviation }\end{array}$ & Median \\
\hline The board size (BS-1) & 10.46 & 17 & 5 & 2.74 & 11 \\
\hline Composition of the Board (BS-2) & 0.69 & 0.75 & 0.54 & 0.051 & 0.69 \\
\hline The board meetings (BS-3) & 6.58 & 13 & 3 & 2.16 & 6 \\
\hline Attendance of each director (BS-4) & 0.802 & 0.92 & 0.65 & 0.048 & 0.8 \\
\hline Expertise (BS-5) & 1 & 1 & 1 & 0 & 1 \\
\hline
\end{tabular}

Source: SPSS Output; Compiled by Researcher

Board structure includes all board activities such as composition, the size, the committees, remuneration, and appointments of director, ownership, and expertise of members of the Board. From the above table, the maximum standard deviation of the factors of board size in the sample is $2.74 \%$, and there is also a much smaller standard deviation of $0 \%$. These figures show that the board structure in both cement and iron and steel companies differed significantly from one firm to another. As seen from the table, board size, which means the total number of internal and external members on the board, was found to be the highest standard deviation of $2.74 \%$ and mean of 10.46. Board composition is the number of directors and its categorization into outsider and insider directors. While Promoters/promoter group, top management, shareholders, and employee forms insiders, outsiders, on the other hand, are those without direct monetary interest in the company. The mean of board composition for 16 companies was 0.69 , with a median of 0.69 . Board composition for this study was calculated as the ratio of the number of outside (non-executive) directors to the total number of directors on the board. Companies were found to have board composition with a maximum value of 0.75 and the most negligible value of 0.54 . The respective standard deviation for board composition in cement, iron, and steel companies was 0.051 . The board meetings were found to have a mean of 6.58 and a standard deviation of 2.16 with a maximum and minimum value of 13 and 3 . The total attendance of directors in board meetings was calculated as the ratio of actual attendance by dependent directors and attendance required by dependent directors. It was found that the mean of total attendance was 0.802 with a standard deviation and median of 0.048 and 0.8 , respectively. The total attendance of directors at board meetings was found to have the highest value of 0.92 and lowest value of 0.65 . Another important factor was the board's expertise, and 
if firms used accounting and finance professionals on board, the data was recorded as one and zero. Hence, the expertise in cement and iron, and steel companies was found to have a mean of 1 with a standard deviation of 0 showing no deviation. The maximum and minimum value of expertise in 16 companies understudy was 1 , indicating that all companies adhere to the law that mandates the appointment of accounting and finance professionals on board.

\section{Testing of Hypothesis}

\section{Hypothesis 1}

Ho1: There is no significant difference among Iron \& Steel and Cement companies with respect to the relationship between board structure and volatility of stock returns.

H1: There is a significant difference among Iron \& Steel and Cement companies with respect to the relationship between board structure and volatility of stock returns.

\section{Board Structure and Volatility in both Cement and Iron and Steel Companies}

Table 2(a): Regression Analysis

\begin{tabular}{l|r|r|r|r|r|}
\hline Model & $\mathrm{R}$ & R Square & $\begin{array}{c}\text { Adjusted R } \\
\text { Square }\end{array}$ & $\begin{array}{c}\text { Std. Error of the } \\
\text { Estimate }\end{array}$ & Durbin-Watson \\
\hline 1 & $.367^{\mathrm{a}}$ & .135 & .557 & .24087 & 1.476 \\
\hline
\end{tabular}
a. Predictors: (Constant), BS_4, BS_1, BS_2, BS_3
b. Dependent Variable: volatility

Source: SPSS Output; Compiled by Researcher

From the above regression analysis shown in Table 2, the value of $\mathrm{R}$ obtained was 0.367 , and the R Square value was 0.135. Further, the adjusted $\mathrm{R}$ square value was found to be 0.557 , which indicated the significance of explanatory variables. The value obtained for the standard error of the estimate is 0.24087 . The value of comparison of coefficient of determination and Durbin - Watson statistic based on the first difference level of data is 1.476.

The Durbin Watson (DW) statistic test for autocorrelation in the residuals from a statistical regression analysis. The Durbin-Watson statistic will always have a value between 0 and 4. A value of 2 means that autocorrelation was not detected in the sample. Values from 0 to less than 2 indicate positive autocorrelation, and values from 2 to 4 indicate negative autocorrelation. The Durbin-Watson statistic obtained was 1.476 , which was between 1.5 and 2.5. The data was auto-correlated.

Interactions in regression are the combined effect of two independent variables on one dependent variable. Interactions in SPSS must be calculated before including them in a model.

\section{Regression ANOVA:}

Analysis of variance (ANOVA) is a collection of statistical models used to analyze the differences among group means and their associated procedures (such as "variation" among and between groups), which was developed by statistician and evolutionary biologist Ronald Fisher. 
Table 2(b): Results of Regressional ANOVA

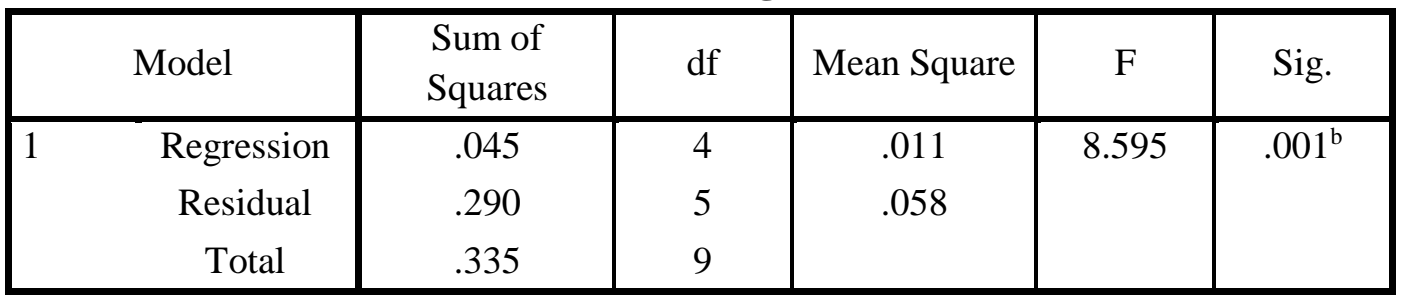

a. Dependent Variable: volatility

b. Predictors: (Constant), BS_4, BS_1, BS_2, BS_3

Source: SPSS Output; Compiled by Researcher

The Regressional ANOVA table revealed significant mean differences in components of board structure and volatility of stock returns. The $\mathrm{F}$ test showed a significant mean difference between these mean scores, with an $F$ value of 8.595 and a significance level of 0.001 less than $\mathrm{p}$ (0.05). This value is compared with the value on the F table (critical value), i.e., 5.19. The value of $\mathrm{F}$ obtained is 8.595 , which is higher than the critical value $5.19, \mathrm{p}=0.001$ is lesser than $\mathrm{p}=0.05$ showing high significance.

Table 2(c): Unstandardized and Standardized Coefficients with $t$ values and significance

\begin{tabular}{|c|c|c|c|c|c|c|}
\hline \multirow{2}{*}{\multicolumn{2}{|c|}{ Model }} & \multicolumn{2}{|c|}{ Unstandardized Coefficients } & \multirow{2}{*}{$\begin{array}{c}\text { Standardized } \\
\text { Coefficients }\end{array}$} & \multirow[b]{2}{*}{$\mathrm{t}$} & \multirow[b]{2}{*}{ Sig. } \\
\hline & & B & Std. Error & & & \\
\hline \multirow[t]{5}{*}{1} & (Constant) & 2.831 & 8.892 & & .318 & .763 \\
\hline & BS_1 & .178 & .398 & .394 & .446 & 674 \\
\hline & BS_2 & -.488 & 7.017 & -.050 & -.070 & .947 \\
\hline & BS_3 & -.091 & .234 & -.542 & -.389 & .713 \\
\hline & BS_4 & -4.502 & 7.404 & -.618 & -.608 & .570 \\
\hline
\end{tabular}

a. Dependent Variable: volatility

Source: SPSS Output; Compiled by Researcher

$B S_{i t}=\beta_{0}+\beta_{1} B S \_1$ i,t $+\beta_{2} B S \_2$ i,t $+\beta_{3} B S \_3$ i,t $+\beta_{4} B S \_4$ i,t

$=2.831+0.394\left(\mathrm{BS} \_1 \mathrm{i}, \mathrm{t}\right)+(-0.50)\left(\mathrm{BS} \_2 \mathrm{i}, \mathrm{t}\right)+(-0.542)\left(\mathrm{BS} \_3 \mathrm{i}, \mathrm{t}\right)+(-0.618)\left(\mathrm{BS} \_4 \mathrm{i}, \mathrm{t}\right)$

The above table shows unstandardized and standardized coefficients with $\mathrm{t}$ values and significance. Unstandardized Coefficient represents the amount by which dependent variables change if one unit changes independent variables, keeping other independent variables constant. The beta values for BS_1, BS_2, BS_3 and BS_4 were found to be 0.178, -0.488, 0.091 and -4.502 . A standardized beta coefficient compares the strength of the effect of each independent variable to the dependent variable and is measured in units of standard deviation. The higher the absolute value of the beta coefficient, the stronger the effect. The standardized coefficient beta values for BS_1, BS_2, BS_3 and BS_4 were found to be 0.398, 7.017, 0.234 and 7.404. 
Table 2(d): Residuals Statistics

\begin{tabular}{|l|r|r|r|r|r|}
\hline & \multicolumn{1}{|c|}{ Minimum } & Maximum & Mean & Std. Deviation & N \\
\hline Predicted Value & .1302 & .3344 & .1921 & .0708 & 10 \\
Residual & -.2028 & .4360 & .0000 & .1795 & 10 \\
Std. Predicted Value & -.872 & 2.008 & .000 & 1.000 & 10 \\
\hline Std. Residual & -.842 & 1.810 & .000 & .745 & 10 \\
\hline
\end{tabular}

a. Dependent Variable: volatility

Source: SPSS Output; Compiled by Researcher

The above table shows the residual statistics in regression which is the difference between the observed value of the dependent variable and the predicted value. The mean of the predicted value was 0.1921 , and the mean of the residual value was 0.00 . The standard deviation of the predicted value was 0.0708, and the standard deviation of the residual value was 0.1795 . Positive values show that the prediction was too low.

Results of hypothesis 1: The effects of regression analysis show a positive relationship between board structure and volatility of stock returns. Hence, the null hypothesis was rejected, and the alternate hypothesis was accepted.

\section{Board Structure and Volatility in Cement Companies}

Table 3: Test of Correlation between board structure and volatility of stock returns in cement companies

\begin{tabular}{|c|c|c|c|c|c|c|c|}
\hline & & volatility & BS_1 & BS_2 & BS_3 & BS_4 & BS_5 \\
\hline \multirow{3}{*}{ volatility } & Pearson Correlation & 1 & .736 & .585 & .026 & -.554 &.${ }^{\mathrm{a}}$ \\
\hline & Sig. (2-tailed) & & .007 & .003 & .007 & .332 & . \\
\hline & $\mathrm{N}$ & 5 & 5 & 5 & 5 & 5 & 5 \\
\hline \multirow{3}{*}{ BS_1 } & Pearson Correlation & .736 & 1 & -.489 & .563 & .131 &.$^{\mathrm{a}}$ \\
\hline & Sig. (2-tailed) & .007 & & .403 & .323 & .833 & . \\
\hline & $\mathrm{N}$ & 5 & 5 & 5 & 5 & 5 & 5 \\
\hline \multirow{3}{*}{ BS_2 } & Pearson Correlation & .585 & -.489 & 1 & .344 & -.839 &.$^{\mathrm{a}}$ \\
\hline & Sig. (2-tailed) & .003 & .403 & & .571 & .076 & . \\
\hline & $\mathrm{N}$ & 5 & 5 & 5 & 5 & 5 & 5 \\
\hline \multirow{3}{*}{ BS_3 } & Pearson Correlation & .026 & .563 & .344 & 1 & -.742 &.$^{\mathrm{a}}$ \\
\hline & Sig. (2-tailed) & .007 & .323 & .571 & & .151 & . \\
\hline & $\mathrm{N}$ & 5 & 5 & 5 & 5 & 5 & 5 \\
\hline \multirow{3}{*}{ BS_4 } & Pearson Correlation & -.554 & .131 & -.839 & -.742 & 1 &.$^{\mathrm{a}}$ \\
\hline & Sig. (2-tailed) & .332 & .833 & .076 & .151 & & . \\
\hline & $\mathrm{N}$ & 5 & 5 & 5 & 5 & 5 & 5 \\
\hline \multirow{3}{*}{ BS_5 } & Pearson Correlation &.$^{\mathrm{a}}$ &.$^{\mathrm{a}}$ &.$^{\mathrm{a}}$ &.$^{\mathrm{a}}$ &.$^{\mathrm{a}}$ &.$^{\mathrm{a}}$ \\
\hline & Sig. (2-tailed) & . & . & . & . & . & \\
\hline & $\mathrm{N}$ & 5 & 5 & 5 & 5 & 5 & 5 \\
\hline
\end{tabular}

a. Cannot be computed because at least one of the variables is constant.

Source: SPSS Output; Compiled by Researcher 
Pearson correlation coefficient for BS_1 and volatility of stock returns is $0.736(\mathrm{p}=0.007)$, which is significant $(\mathrm{p}<0.01)$ for a two-tailed test), based on 10 complete observations (i.e., cases with non-missing values for both BS_1 and volatility of stock returns). Pearson correlation coefficient for BS_2 and volatility of stock returns is 0.585 ( $\mathrm{p}=0.003)$, which is significant ( $\mathrm{p}<0.01$ ) for a two-tailed test), based on 10 complete observations (i.e., cases with non-missing values for both BS_2 and volatility of stock returns). Pearson correlation coefficient for BS_3 and volatility of stock returns is $0.026(\mathrm{p}=0.007)$, which is significant ( $p<0.01$ ) for a two-tailed test), based on 10 complete observations (i.e., cases with non-missing values for both BS_3 and volatility of stock returns). Pearson correlation coefficient for BS_4 and volatility of stock returns is $-0.554(\mathrm{p}=0.332)$, which is not significant $(\mathrm{p}>0.01)$ for a twotailed test), based on 10 complete observations (i.e., cases with non-missing values for both BS_4 and volatility of stock returns). The other important factor, BS_5, was the board's expertise, which meant if firms used accounting and finance professionals on board and all companies were found to adhere to the law that mandates the appointment of accounting and finance professionals on board.

\section{Board Structure and Volatility in Iron and Steel Companies}

Table 4: Test of Correlation between board structure and volatility of stock returns in Iron and Steel Companies

\begin{tabular}{|c|c|c|c|c|c|c|c|}
\hline & & volatility & BS_1 & BS_2 & BS_3 & BS_4 & BS_5 \\
\hline \multirow{3}{*}{ volatility } & Pearson Correlation & 1 & .147 & .153 & .156 & .118 &.$^{\mathrm{a}}$ \\
\hline & Sig. (2-tailed) & & .014 & .005 & .002 & .850 & . \\
\hline & $\mathrm{N}$ & 5 & 5 & 5 & 5 & 5 & 5 \\
\hline \multirow{3}{*}{ BS_1 } & Pearson Correlation & -.147 & 1 & .685 & .783 & -.212 &.$^{\mathrm{a}}$ \\
\hline & Sig. (2-tailed) & .814 & & .202 & .118 & .732 & . \\
\hline & $\mathrm{N}$ & 5 & 5 & 5 & 5 & 5 & 5 \\
\hline \multirow{3}{*}{ BS_2 } & Pearson Correlation & -.153 & .685 & 1 & $.988^{* * *}$ & -.744 &.$^{\mathrm{a}}$ \\
\hline & Sig. (2-tailed) & .805 & .202 & & .002 & .149 & . \\
\hline & $\mathrm{N}$ & 5 & 5 & 5 & 5 & 5 & 5 \\
\hline \multirow{3}{*}{ BS_3 } & Pearson Correlation & -.156 & .783 & $.988^{* * *}$ & 1 & -.705 &.$^{\mathrm{a}}$ \\
\hline & Sig. (2-tailed) & .802 & .118 & .002 & & .184 & . \\
\hline & $\mathrm{N}$ & 5 & 5 & 5 & 5 & 5 & 5 \\
\hline \multirow{3}{*}{ BS_4 } & Pearson Correlation & .118 & -.212 & -.744 & -.705 & 1 &.$^{\mathrm{a}}$ \\
\hline & Sig. (2-tailed) & .850 & .732 & .149 & .184 & & . \\
\hline & $\mathrm{N}$ & 5 & 5 & 5 & 5 & 5 & 5 \\
\hline \multirow{3}{*}{ BS_5 } & Pearson Correlation &.$^{\mathrm{a}}$ &.$^{\mathrm{a}}$ &.$^{\mathrm{a}}$ &.$^{\mathrm{a}}$ &.$^{\mathrm{a}}$ &.$^{\mathrm{a}}$ \\
\hline & Sig. (2-tailed) & . & . & . & . & . & \\
\hline & $\mathrm{N}$ & 5 & 5 & 5 & 5 & 5 & 5 \\
\hline
\end{tabular}

**. Correlation is significant at the 0.01 level (2-tailed).

a. Cannot be computed because at least one of the variables is constant.

Source: SPSS Output; Compiled by Researcher 
Pearson correlation coefficient for BS_1 and volatility of stock returns is $0.147(\mathrm{p}=0.014)$, which is significant ( $\mathrm{p}<0.01)$ for a two-tailed test), based on 10 complete observations (i.e., cases with non-missing values for both BS_1 and volatility of stock returns). Pearson correlation coefficient for BS_2 and volatility of stock returns is $0.153(\mathrm{p}=0.005)$, which is significant ( $\mathrm{p}<0.01)$ for a two-tailed test), based on 10 complete observations (i.e., cases with non-missing values for both BS_2 and volatility of stock returns). Pearson correlation coefficient for BS_3 and volatility of stock returns is $0.156(\mathrm{p}=0.002)$, which is significant ( $\mathrm{p}<0.01$ ) for a two-tailed test), based on 10 complete observations (i.e., cases with non-missing values for both BS_3 and volatility of stock returns). Pearson correlation coefficient for BS_4 and volatility of stock returns is $0.118(\mathrm{p}=0.850)$, which is not significant ( $\mathrm{p}>0.01)$ for a twotailed test), based on 10 complete observations (i.e., cases with non-missing values for both BS_4 and volatility of stock returns). The other important factor, BS_5, was the board's expertise, which meant if firms used accounting and finance professionals on board and all companies were found to adhere to the law that mandates the appointment of accounting and finance professionals on board.

\section{Conclusion}

The study considered cement, iron, and steel companies listed on the Bombay Stock Exchange (BSE) to assess the relationship between board structure and volatility of stock returns. The relationship between board structure and volatility of stock returns was tested using SPSS through descriptive statistics, f-test, and multiple regression models. It was found that board structure possessed a positive relationship with the volatility of stock returns during the study period. An examination of corporate governance practices such as board structure may help to understand the existing practices of corporate governance to help in designing effective standard practices for the future. The return on a stock is the key factor to stock market investment success. Hence, the study was conducted to strengthen corporate governance and improve their practices for better performance of the companies.

\section{References}

- Fox, M. B., \& Heller, M. A. (2000). Corporate governance lessons from Russian enterprise fiascoes. NYUL Rev., 75, 1720.

- Manna, A., Sahu, T. N., \& Gupta, A. (2016). Impact of Ownership Structure and Board Composition on Corporate Performance in Indian Companies. Indian Journal of Corporate Governance, 9(1), 44-66.

- Raei, Reza (1998). Designing an appropriate investment model in the stock portfolio using artificial intelligence (neural networks). University of Tehran, Tehran, Iran.

- Raei-R. and Saidi-A. Basics of financial engineering and risk management. The Study and Compilation of Humanities Books (position), 2004.

- Roy, A. (2016). Corporate Governance and Firm Performance: A Study of Indian Listed Firms. Metamorphosis, 15(1), 31-46. 
- Tusiime, I., Nkundabanyanga, S. K., \& Nkote, I. N. (2011). Corporate governance: Ownership structure, board structure, and performance of public sector entities. Journal of Public Administration and Policy Research, 3(9), 250.

- Annual Reports of Iron and Steel Companies, 2011-18

- Annual Reports of Cement Companies, 2011-18

- www.sebi.gov.in 